\title{
Leptospirosis as an important differential of pulmonary haemorrhage on the intensive care unit: a case managed with VV-ECMO
}

\author{
James Barnacle ${ }^{1 *}$, Stefan Gurney ${ }^{2}$, Stephane Ledot $^{3}$ and Suveer Singh ${ }^{3}$
}

\begin{abstract}
Background: Leptospirosis is a potentially fatal zoonosis. It can cause a wide range of symptoms, including diffuse alveolar haemorrhage which occurs in a minority of cases but carries a mortality of over $70 \%$. These patients may present with severe acute respiratory failure. The differential diagnosis for diffuse alveolar haemorrhage is broad whereas prompt diagnosis and treatment can be lifesaving.

Case presentation: A 20-year-old previously fit and well trout farm worker presented with a 3-day history of malaise, fevers, diarrhoea, vomiting and jaundice. He developed haemoptysis, severe headaches, neck stiffness and photophobia on the day of emergency admission. He was anaemic and thrombocytopenic. Anuric acute kidney injury (urea 32, creat 507) required immediate haemofiltration. In view of progressive respiratory failure with fourquadrant lung infiltrates on imaging, he was given broad spectrum antibiotics and pulsed methylprednisolone empirically, in case of a vasculitic pulmonary-renal presentation. He was intubated within $48 \mathrm{~h}$ of admission. Despite attempted protective ventilatory management, he remained hypoxaemic and developed pneumomediastinum. He was retrieved to a specialist cardiorespiratory intensive care unit on femoro-femoral mobile W-ECMO. Three days from admission, results showed positive Leptospira IgM and real-time PCR. Serial bronchoscopies showed old and fresh clots, but not the classical progressive late red tinge of the returned lavage fluid. After eight days, W-ECMO was weaned, he was extubated three days later, and made a full recovery. At 9 months follow-up, he was clinically better, with resolution of the CT scan findings and near normal lung function, albeit with low normal gas transfer.

Conclusions: Leptospirosis is a rare but important differential to be considered in diffuse alveolar haemorrhage presenting to the ICU, especially in young males. A thorough history for occupational or recreational risk factors may offer the diagnostic clue. Most patients recover fully with antibiotics. However, resulting acute severe respiratory failure can ensue. In this situation, early consideration for respiratory ECMO support offers time for clearance of endobronchial clot, parenchymal recovery, and prevention of ventilator-induced lung injury. Steroids have no clear evidence but may be used to avoid delay in treating suspected vasculitic or autoimmune causes of diffuse alveolar haemorrhage.
\end{abstract}

Keywords: Leptospirosis, Extra-corporeal membrane oxygenation, Pulmonary haemorrhage, Diffuse alveolar haemorrhage, Weil's disease

\footnotetext{
* Correspondence: james.barnacle1@nhs.net

'Department of Infectious Diseases, St Mary's Hospital, Imperial College Healthcare NHS Trust, London, UK

Full list of author information is available at the end of the article
}

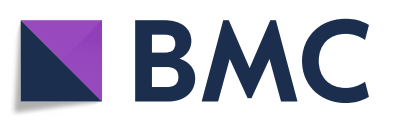

( ) The Author(s). 2020 Open Access This article is licensed under a Creative Commons Attribution 4.0 International License, which permits use, sharing, adaptation, distribution and reproduction in any medium or format, as long as you give appropriate credit to the original author(s) and the source, provide a link to the Creative Commons licence, and indicate if changes were made. The images or other third party material in this article are included in the article's Creative Commons licence, unless indicated otherwise in a credit line to the material. If material is not included in the article's Creative Commons licence and your intended use is not permitted by statutory regulation or exceeds the permitted use, you will need to obtain permission directly from the copyright holder. To view a copy of this licence, visit http://creativecommons.org/licenses/by/4.0/. The Creative Commons Public Domain Dedication waiver (http://creativecommons.org/publicdomain/zero/1.0/) applies to the data made available in this article, unless otherwise stated in a credit line to the data. 


\section{Background}

Leptospirosis is a zoonotic bacterial infection caused by the spirochaete Leptospira spp. Public Health England reported 92 lab-confirmed cases of leptospirosis in the UK in 2017 [1]. Transmission usually occurs through contact with the urine of infected rodents. Symptoms are frequently mild and flu-like, although severe complications may occur. Jaundice and renal failure secondary to leptospirosis is termed Weil's disease after the $19^{\text {th }}$ Century German physician Adolf Weil. Renal failure tends to be non-oliguric and reversible.

Diffuse alveolar haemorrhage (DAH) occurs in approximately $3.7 \%$ of leptospirosis cases and is the major cause of death, with mortality rates exceeding 70\% [2]. The differential diagnosis is broad and either pulmonary capillaritis, bland pulmonary haemorrhage, or diffuse alveolar damage may be seen on histology [3]. Traditionally, severe bleeding has been a relative contraindication to extra-corporeal membrane oxygenation (ECMO), which requires systemic anticoagulation to maintain circuit patency. However, cases have been reported of DAH successfully managed using ECMO [4].

Here, we present a case of leptospirosis presenting as $\mathrm{DAH}$ and multi-organ failure, requiring support with veno-venous ECMO (VV-ECMO). This case demonstrates the importance of considering rarer causes such as leptospirosis amongst the differentials of severe acute respiratory failure due to pulmonary haemorrhage.

\section{Case presentation}

A 20-year-old male trout farm worker presented to his local hospital with a 3-day history of malaise, fevers, diarrhoea, vomiting and jaundice. He developed haemoptysis, severe headaches, neck stiffness and photophobia, leading to emergency admission. There were no rashes, swellings, nor melaena. He had no significant past medical history and was taking no prescription medications. He was an occasional smoker and alcohol drinker. He remained hypoxic despite supplemental oxygen and after a short admission to the high-dependency unit he was intubated and ventilated in the intensive care unit (ICU). A post-intubation chest $\mathrm{x}$-ray showed fourquadrant airspace 'ground glass' opacification (Fig. 1). His admission bloods demonstrated haemoglobin $(\mathrm{Hb}) 99 \mathrm{~g} / \mathrm{l}$,

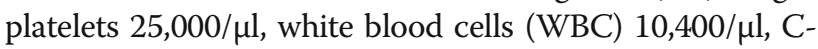
reactive protein (CRP) $195 \mathrm{mg} / \mathrm{dl}$, creatinine $392 \mu \mathrm{mol} / \mathrm{l}$, urea $17 \mathrm{mmol} / \mathrm{l}$ and total bilirubin $117 \mu \mathrm{mol} / \mathrm{l}$. HIV, autoimmune, vasculitis and atypical pneumonia blood and/or urine screens were negative.

Empirical ceftriaxone was initiated following sequential escalating regimens of amoxicillin, gentamicin, metronidazole, then piperacillin-tazobactam and levofloxacin, following local microbiology advice. Intravenous doses of $1 \mathrm{~g}$ methylprednisolone daily for two days

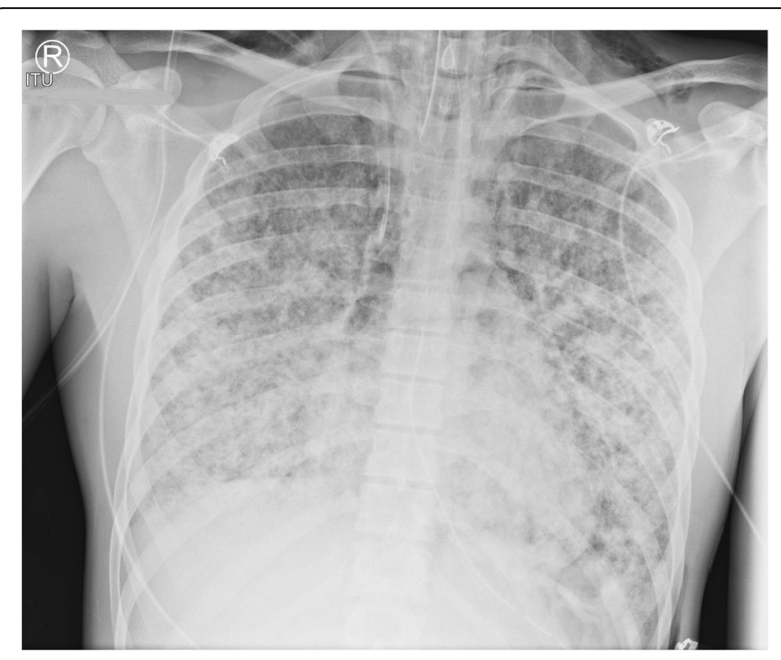

Fig. 1 Chest X-ray of patient on admission to local hospital post-intubation

were initiated to treat the possibility of vasculitis associated pulmonary haemorrhage, pending results. He received early renal replacement therapy for acute kidney injury (AKI). A high-resolution CT scan of the chest after intubation demonstrated pneumomediastinum, pneumoperitoneum and extensive dependent consolidation. Due to the risk of worsening pneumothoraces and ventilator-induced lung injury (VILI) on optimised conventional ventilatory management, and concerns about the risk of prone positioning in this context, he was accepted for retrieval on the national severe acute respiratory failure (SARF) pathway. At the time of referral, he had $\mathrm{SpO}_{2} 94 \%, \mathrm{pO}_{2} 11.4 \mathrm{kPa}, \mathrm{pCO}_{2} 6.5 \mathrm{kPa}$ and $\mathrm{pH} 7.29$ on pressure-controlled ventilation with $\mathrm{FiO}_{2}$ 1.0, positive end-expiratory pressure (PEEP) $15 \mathrm{cmH}_{2} \mathrm{O}$, total inspiratory pressure $\left(P_{\text {insp. }}\right) 30 \mathrm{cmH}_{2} \mathrm{O}$, tidal volume $\left(V_{\mathrm{T}}\right) 450$ $\mathrm{ml}$, compliance $30 \mathrm{ml} / \mathrm{cmH}_{2} \mathrm{O}, \quad \mathrm{PaO}_{2} / \mathrm{FiO}_{2}$ ratio $86 \mathrm{mmHg}$ and a Murray score of 3.75 . He was commenced on VV-ECMO (using a standard bi-femoral configuration: 25-French access cannula and a 23French return cannula) at 2930 revolutions per minute (RPM), generating a blood flow rate of $4.7 \mathrm{~L} / \mathrm{min}$ with a sweep gas flow of $5.0 \mathrm{~L} / \mathrm{min}$ of $100 \%$ oxygen to facilitate lung protective ventilation.

At this ECMO centre, a further high-resolution CT scan was performed demonstrating persistent consolidation with pronounced branching nodularity and extensive mediastinal emphysema (Fig. 2a) with a normal CT head, abdomen and pelvis. The pneumomediastinum prevented a full echocardiographic examination but subcostal windows demonstrated preserved left ventricular function, non-dilated ventricles and no significant mitral or tricuspid regurgitation. On day 1 of his time on ECMO, positive serum Leptospira Panbio IgM ELISA and dual-target real-time $16 \mathrm{SrRNA} /$ Lipl32 polymerase 


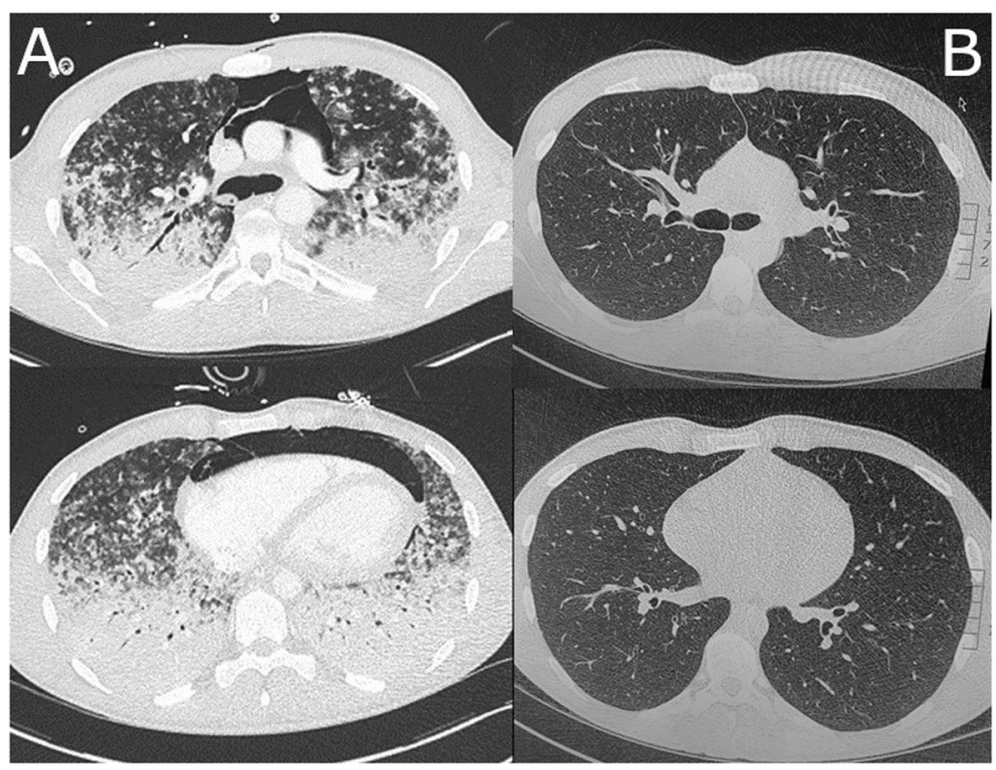

Fig. 2 High-resolution CT images on day 1 of ECMO (a) and 9 months post-discharge (b)

chain reaction (PCR) results became available, confirmed by the reference laboratory, to which Public Health England was alerted. Further tests including blood $\beta$-d-glucan and galactomannan, as well as cultures, mycoplasma, viral PCR screen and acid-fast bacilli (AFB) from broncho-alveolar lavage (BAL) were all negative.

*Top images at the level of the carina; bottom images at the level of the superior pulmonary veins

The patient was kept on lung-protective ventilation using bi-level positive airway pressure (BiPAP) with PEEP $5 \mathrm{cmH}_{2} \mathrm{O}, P_{\text {insp. }} 12 \mathrm{cmH}_{2} \mathrm{O}$ and $V_{\mathrm{T}} 250-300 \mathrm{ml}$, rate $10 / \mathrm{min}$. He was sedated and paralysed with a cisatracurium infusion for the first $24 \mathrm{~h}$. He received lowdose noradrenaline to keep his mean arterial pressure (MAP) above $65 \mathrm{mmHg}$ but no inotropic support. Haemodiafiltration with regional citrate-based anticoagulation was required until day seven of the admission. Methylprednisolone was continued at a maintenance dose of $60 \mathrm{mg}$ bd for 4 days until the full vasculitic screen had come back negative, with fluconazole added prophylactically in view of the steroid burden. Ceftazidime and gentamicin were started empirically for rising inflammatory markers and fever on day 6 of ECMO and continued for 7 days. The patient received 8 days of ECMO support. His coagulation studies were normal throughout the admission, but his platelets were $56,000 /$ $\mu \mathrm{l}$ on arrival, with a prior nadir of $25,000 / \mu \mathrm{l}$. Systemic heparinisation was therefore initiated cautiously with a target anti-Xa level of $0.2-0.3 \mathrm{IU} / \mathrm{ml}$ according to local policy.

Serial bronchoscopic examination by an experienced bronchoscopist initially showed old clots in the lower lobes bilaterally but on day 3 of the ECMO run, fresh blood was seen with mucosal bleeding points in the apical segments of the right and left lower lobes; these were treated with $2 \mathrm{ml}$ of 1:100,000 adrenaline to achieve haemostasis. There was no central airway source of bleeding on careful inspection. His anti-Xa target was reduced to $0.2 \mathrm{IU} / \mathrm{ml}$ and tranexamic acid $1 \mathrm{~g}$ IV bd was commenced. A liver ultrasound was normal, hepatitis A and $\mathrm{E}$ serology was negative and a review from hepatology confirmed that the enzyme picture fitted leptospirosis and treatment should be supportive.

On day 9 at the Royal Brompton Hospital, the patient was decannulated from ECMO whilst still receiving lung protective ventilation. The patient was extubated three days post-ECMO decannulation. A post-decannulation vascular ultrasound revealed no deep vein thromboses and he was treated with 5000 units of unfractionated heparin subcutaneously twice daily, in view of his abnormal renal function and restored platelet counts. He was extubated 3 days after decannulation from ECMO and repatriated to his local hospital where he made a full recovery.

At 9 months follow-up, he was clinically better, with resolution of the CT scan findings (Fig. 2b), a normal 6min walk test distance $>400 \mathrm{~m}$, and near normal lung function, albeit with low normal gas transfer (FEV1 5.68 $\mathrm{L},>100 \%$, VC $6.7 \mathrm{~L},>100 \%$, TLCO 79.8\%, KCO 74.2\%).

\section{Discussion}

Diffuse alveolar haemorrhage

Diffuse alveolar haemorrhage is caused by disruption of the alveolar-capillary basement membrane. It can have a 
mortality exceeding $50 \%$ in the intensive care setting and is traditionally associated with haemoptysis, although this may be absent in a significant proportion of patients [5]. Radiological features include a non-specific diffuse infiltrative opacification pattern on chest X-ray and ground-glass opacities on CT in acute bleeding [6]. It carries a wide differential diagnosis including vasculitis, infection, drugs, acute respiratory distress syndrome and heart failure [3]. In leptospirosis, pulmonary haemorrhage has been the presenting sign preceding other clinical features [7]. In patients admitted to the ICU with undifferentiated pulmonary haemorrhage, leptospirosis should be considered even in the absence of other typical features. DAH does not always present with classical BAL findings, as was the case here. There was evidence of clotted appearances interspersed with fresh blood. This was probably related to the delay between initial presentation with haemoptysis and the BAL, which was only performed after the initiation of ECMO. By this time, some interalveolar and endobronchial clotting would have commenced. It remains speculative as to whether the classical BAL findings would have been found if BAL was performed at the referring centre at presentation or soon after intubation. However, we did not find an alternative source, and no alternative microbiology became apparent from the ECMO BAL samples.

\section{Leptospirosis}

Leptospirosis is a zoonotic disease caused by the aerobic spirochaete Leptospira spp. It is spread through contact with the urine of mammals, usually rodents. Portals of entry include skin abrasions, mucous membranes or conjunctivae; it is unclear whether the bacteria can penetrate intact skin. Diagnosis is usually made using serology tests including IgM enzyme-linked immunosorbent assay (ELISA). However, rapid diagnostics by blood PCR are also available [8]. Leptospira can be cultured but it requires special media. Growth is observed beyond a week and may take up to 3 months meaning routine blood cultures will be negative [9].

Clinically, leptospirosis is a biphasic illness with an acute febrile leptospiraemic phase lasting about a week, followed by an immune leptospiruric phase characterised by antibody production during which most of the complications occur. The average incubation period for leptospirosis is 10 days. Most cases involve a mild, flulike, self-limiting illness or may be subclinical. However, there are many clinical manifestations. Fever, myalgia and headache are almost universal. In addition, conjunctival suffusion, non-productive cough, abdominal pain, nausea, vomiting and diarrhoea are commonly seen in over one third of patients [9]. The mortality for anicteric leptospirosis is very low. Neurological complications may be seen, the most common of which is aseptic meningitis with a lymphocytic predominance. Laboratory studies are non-specific. White cells are typically normal, and thrombocytopenia may occur.

Icteric leptospirosis, or leptospirosis with jaundice, occurs in $5-10 \%$ of cases and heralds a more severe clinical course. Weil's disease is the term used for leptospirosis complicated by jaundice and renal failure. The jaundice is not associated with hepatic necrosis and any liver dysfunction returns to normal after recovery. Renal failure tends to be nonoliguric and recovery is generally complete, although renal replacement may be required in the acute phase. Mortality for Weil's disease in the UK is around 5\% [10].

Treatment of leptospirosis is mainly supportive. The efficacy of antibiotics remains unclear. A Cochrane review demonstrated a non-significant trend towards shortening the duration of clinical illness only [11]. In practice, antibiotics are recommended, especially for severe disease. Leptospirosis is susceptible to a wide range of antibiotics and resistance does not seem to be a problem. Traditionally treatment is with a penicillin or doxycycline, but cephalosporins or azithromycin are acceptable alternatives. When comparing penicillin, doxycycline and cephalosporins, no benefit has been found in using one over another [11].

\section{ECMO support in leptospirosis}

There are 10 other reports of the use of ECMO in the management of leptospirosis: 9 veno-venous, and 1 venoarterial (Table 1). Common characteristics include male gender and young age (average 39 years, 20 to 72 years). The duration of ECMO was 2-18 days in survivors, typically 1 week. All patients received at least a penicillin or cephalosporin. Almost all patients had a convincing transmission source, either occupational or recreational, which highlights the importance of a thorough collateral history in suspected cases of leptospirosis. Including this case, mortality was $1 / 11$ (9.1\%) amongst ECMO patients at discharge, which is much lower than the reported mortality of over $50 \%$ in acute respiratory failure in an ICU context without ECMO [2, 12].

$V V$ veno-venous, $V A$ veno-arterial, RHZE rifampicin, isoniazid, pyrazinamide, ethambutol

Leptospirosis with DAH appears to carry a high risk of barotrauma [19, 23, 24] The current case was complicated by pneumomediastinum. One report of acute respiratory failure managed without ECMO reported spontaneous pneumomediastinum and recurrent airway occlusion due to haemorrhage and required a six-week ICU admission and tracheostomy [24]. Our patient had a much better clinical course despite the use of ECMO.

\section{Steroid treatment in leptospirosis with diffuse alveolar haemorrhage}

The evidence for steroids in severe leptospirosis is insufficient to recommend their routine use. A meta-analysis 
Table 1 Cases in the literature reporting the use of $\mathrm{W}$-ECMO in leptospirosis

\begin{tabular}{|c|c|c|c|c|c|c|c|c|}
\hline & Country & $\begin{array}{l}\text { Age } \\
\text { (sex) }\end{array}$ & Transmission & Treatment & $\begin{array}{l}\text { Time from } \\
\text { admission } \\
\text { to ECMO }\end{array}$ & $\begin{array}{l}\text { ECMO } \\
\text { modality }\end{array}$ & $\begin{array}{l}\text { ECMO } \\
\text { duration } \\
\text { (days) }\end{array}$ & Outcome \\
\hline Our patient & UK & $\begin{array}{l}20 \\
(M)\end{array}$ & Trout farmer & $\begin{array}{l}\text { Levofloxacin } \\
\text { Ceftriaxone } \\
\text { Doxycycline } \\
\text { Methylpred. }\end{array}$ & 4 days & W & 8 & Full recovery \\
\hline $\begin{array}{l}\text { Chaikajornwat } \\
\text { et al. (2020) [13] }\end{array}$ & Thailand & $\begin{array}{l}39 \\
(\mathrm{M})\end{array}$ & $\begin{array}{l}\text { Street vendor } \\
\text { (presumed floodwater } \\
\text { exposure) }\end{array}$ & $\begin{array}{l}\text { Levofloxacin } \\
\text { Ceftriaxone } \\
\text { Methylpred. }\end{array}$ & $12 \mathrm{~h}$ & W & 8 & Full recovery \\
\hline $\begin{array}{l}\text { Cantwell et al. } \\
(2017)[14]\end{array}$ & Chile & $\begin{array}{l}39 \\
(\mathrm{M})\end{array}$ & $\begin{array}{l}\text { Working in a } \\
\text { contaminated drain } \\
\text { with mice }\end{array}$ & $\begin{array}{l}\text { Ceftriaxone } \\
\text { Metronidazole } \\
\text { Meropenem } \\
\text { Vancomycin } \\
\text { Amikacin }\end{array}$ & 1 day & W & 8 & Full recovery \\
\hline $\begin{array}{l}\text { Kutlesa and } \\
\text { Gjurasin (2017) [15] }\end{array}$ & Croatia & $\begin{array}{l}72 \\
(\mathrm{~F})\end{array}$ & $\begin{array}{l}\text { Daily contact } \\
\text { with bulls }\end{array}$ & $\begin{array}{l}\text { Ceftriaxone } \\
\text { Flucloxacillin } \\
\text { Methylpred. }\end{array}$ & 1 day & W & 6 & Full recovery \\
\hline $\begin{array}{l}\text { Ludwig et al. } \\
\text { (2017) [16] }\end{array}$ & Germany & $\begin{array}{l}34 \\
(\mathrm{M})\end{array}$ & Pet rat & $\begin{array}{l}\text { Tazocin } \\
\text { Ciprofloxacin } \\
\text { Prednisolone }\end{array}$ & $12 \mathrm{~h}$ & W & $<1$ & Died \\
\hline $\begin{array}{l}\text { Pardinas et al. } \\
\text { (2017) [17] }\end{array}$ & USA & $\begin{array}{l}32 \\
(\mathrm{M})\end{array}$ & $\begin{array}{l}\text { Freshwater } \\
\text { swimming }\end{array}$ & $\begin{array}{l}\text { Ceftriaxone } \\
\text { Doxycycline }\end{array}$ & 2 days & W & 18 & Full recovery \\
\hline $\begin{array}{l}\text { Umei and Ichiba } \\
\text { (2017) [18] }\end{array}$ & Japan & $\begin{array}{l}50 \\
(\mathrm{M})\end{array}$ & $\begin{array}{l}\text { Occupational } \\
\text { (sushi chef) }\end{array}$ & $\begin{array}{l}\text { Ceftriaxone } \\
\text { Levofloxacin } \\
\text { Minocycline } \\
\text { Vancomycin } \\
\text { Meropenem } \\
\text { Benzylpenicillin } \\
\text { RHZE }\end{array}$ & 3 days & W & 11 & Full recovery \\
\hline Héry et al. (2015) [19] & Laos & $\begin{array}{l}38 \\
(\mathrm{M})\end{array}$ & Visiting rice fields & $\begin{array}{l}\text { Ceftriaxone } \\
\text { Doxycycline } \\
\text { Amoxicillin }\end{array}$ & $<1$ day & W & 9 & Full recovery \\
\hline Liao et al. (2015) [20] & Taiwan & $\begin{array}{l}32 \\
(\mathrm{M})\end{array}$ & $\begin{array}{l}\text { Walking barefoot } \\
\text { through water at } \\
\text { fruit market }\end{array}$ & $\begin{array}{l}\text { Penicillin G } \\
\text { Levofloxacin }\end{array}$ & 1 day & W & 6 & Full recovery \\
\hline Kahn et al. (2006) [21] & Austria & $\begin{array}{l}? ? \\
(\mathrm{M})\end{array}$ & Unknown & $\begin{array}{l}\text { Augmentin } \\
\text { Clarithromycin } \\
\text { Imipenem } \\
\text { Ciprofloxacin }\end{array}$ & Unknown & VA & 2 & Full recovery \\
\hline $\begin{array}{l}\text { Arokianathan et al. } \\
\text { (2005) [22] }\end{array}$ & UK & $\begin{array}{l}30 \\
(\mathrm{M})\end{array}$ & $\begin{array}{l}\text { Clearing sewage } \\
\text { (bare hands with } \\
\text { abrasions) }\end{array}$ & $\begin{array}{l}\text { Cefuroxime } \\
\text { Clarithromycin } \\
\text { Metronidazole } \\
\text { Benzylpenicillin }\end{array}$ & Unknown & W & 7 & Full recovery \\
\hline
\end{tabular}

found just four trials looking at steroid use [25], all of which had study limitations [26-29]. Our patient received two doses of $1 \mathrm{~g}$ methylprednisolone followed by $1 \mathrm{mg} / \mathrm{kg}$ maintenance to treat any possible underlying vasculitic process prior to the diagnosis. Ludwig et al. gave $1 \mathrm{~g}$ of IV prednisolone in combination with an extracorporeal cytokine absorbent filter shortly before their patient died [16]. Kutlesa and Gjurasin gave methylprednisolone for 10 days but the dose is not recorded [15]. Chaikajornwat et al. gave $250 \mathrm{mg}$ methylprednisolone every $6 \mathrm{~h}$ for the first 2 days of their patient's admission in case of vasculitis [13]. Further trials examining the role of steroids in leptospirosis are required, but in the context of pulmonary haemorrhage without a solid diagnosis, steroids should be considered to treat possible vasculitic causes.

\section{Conclusions}

Leptospirosis is a rare but important differential to be considered in diffuse alveolar haemorrhage presenting to the ICU in acute respiratory failure, especially in young males. A thorough history for occupational or recreational risk factors is crucial and if in doubt leptospirosis serology and PCR should be sent. Most patients make a full recovery with treatment, but barotrauma does seem to be associated with DAH in leptospirosis and ECMO support should be considered early to avoid harm from non-protective ventilation. There is no clear evidence for 
steroids in confirmed leptospirosis and their use cannot be recommended. However, they are often instituted empirically prior to diagnosis in case of vasculitic causes for pulmonary haemorrhage. Unfortunately, leptospirosis continues to cause the greatest mortality and morbidity in low- and middle-income countries where access to ECMO is severely limited. In the future, the encouraging outcomes of patients managed with ECMO should be considered when arguing for the introduction of ECMO programmes in high-burden countries.

\begin{abstract}
Abbreviations
ADAMSTS13: A disintegrin and metalloproteinase with thrombospondin type 1 motif, member 13; AFB: Acid-fast bacilli; AKI: Acute kidney injury;

BAL: Broncho-alveolar lavage; BiPAP: Bi-level positive airway pressure; CT: Computer tomography; DAH: Diffuse alveolar haemorrhage; ECMO: Extracorporeal membrane oxygenation; ELISA: Enzyme-linked immunosorbent assay; FEV1: Forced expiratory volume over 1 second; Hb: Haemoglobin; ICU: Intensive care unit; IV: Intravenous; KCO: Transfer coefficient; MAP: Mean arterial pressure; $\mathrm{PCO}_{2}$ : Carbon dioxide partial pressure; $\mathrm{PCR}$ : Polymerase chain reaction; PEEP: Positive end-expiratory pressure; PHE: Public Health England; $P_{\text {insp: }}$ : Total inspiratory pressure; $\mathrm{pO}_{2}$ : Oxygen partial pressure; RHZE: Rifampicin, isoniazid, pyrazinamide, ethambutol; RPM: Revolutions per minute; TLCO: Diffusing capacity for carbon monoxide; VC: Vital capacity; $V_{T}$ : Tidal volume; $\mathrm{W}$-ECMO: Veno-venous extra-corporeal membrane oxygenation; WBC: White blood cells
\end{abstract}

\section{Acknowledgements}

We thank the National Leptospirosis Service based at the Rare and Imported Pathogens Lab, PHE Porton for testing.

\section{Authors' contributions}

JB wrote the manuscript. SG, SS and SL reviewed and edited the manuscript. All authors read and approved the final manuscript.

\section{Funding}

No funding received.

\section{Availability of data and materials}

Not applicable.

\section{Ethics approval and consent to participate}

Not applicable.

\section{Consent for publication}

Written consent for publication was obtained from the patient for the publication of this case report.

\section{Competing interests}

The authors declare that they have no competing interests.

\section{Author details \\ 'Department of Infectious Diseases, St Mary's Hospital, Imperial College Healthcare NHS Trust, London, UK. ${ }^{2}$ Intensive Care Unit, Bristol Royal Infirmary, University Hospitals Bristol NHS Trust, Bristol, UK. ${ }^{3}$ Adult Intensive Care Unit, Royal Brompton Hospital, Royal Brompton and Harefield NHS Trust, London, UK.}

Received: 16 March 2020 Accepted: 13 April 2020

Published online: 26 April 2020

\section{References}

1. Public Health England. Zoonoses Overview Report UK 2017. Public Health England. 2018.

2. Gouveia EL, Metcalfe J, de Carvalho ALF, Aires TSF, Villasboas-Bisneto JC, Queirroz A, et al. Leptospirosis-associated severe pulmonary hemorrhagic syndrome, Salvador. Brazil. Emerging Infectious Diseases. 2008;14(3):505-8.
3. Park SP. Diffuse alveolar haemorrhage. Tuberc Respir Dis (Seoul). 2013;74(4): 151-62.

4. Abrams D, Agerstrand CL, Biscotti M, Burkart KM, Bacchetta M, Brodie D. Extracorporeal membrane oxygenation in the management of diffuse alveolar hemorrhage. ASAIO J. 2015;61(2):216-8.

5. Rabe C, Appenrodt B, Hoff C, Ewig S, Klehr HU, Sauerbruch T, et al. Severe respiratory failure due to diffuse alveolar hemorrhage: clinical characteristics and outcome of intensive care. Journal of Critical Care. 2010;25(2):230-5.

6. Cortese G, Nicali R, Placido R, Gariazzo G, Anro P. Radiological aspects of diffuse alveolar haemorrhage. Radiol Med. 2008;113(1):16-28.

7. Allen P, Raftery S, Phelan D. Massive pulmonary haemorrhage due to leptospirosis. Intensive Care Med. 1989;15(5):322-4.

8. Goris MGA, Leeflang MMG, Loden M, Wagenaar JFP, Klatser PR, Hartskeerl RA, et al. Prospective Evaluation of Three Rapid Diagnostic Tests for Diagnosis of Human Leptospirosis. PLoS Negl Trop Dis. 2013;7(7):e2290.

9. Levett P. Leptospirosis. Clinical Microbiology Reviews. 2001;14(2):296-326.

10. Forbes AE, Zochowski WJ, Dubrey SW, Sivaprakasam V. Leptospirosis and Weil's disease in the UK. QJM: An International Journal of Medicine. 2012; 105(12):1151-62.

11. Brett-Major DM, Coldren R. Antibiotics for leptospirosis. Cochrane Database Syst Rev. 2012;(2):CD008264. Available from. https://doi.org/10.1002/ 14651858.CD008264.pub2.

12. Vieira SRR, Braune JS. Leptospirosis as a cause of acute respiratory failure: clinical features and outcome in 35 critical care patients. Braz J Infect Dis. 2002;6(3):135-9.

13. Chaikajornwat J, Rattanajiajaroen P, Srisawat N, Kawkitinarong K. Leptospirosis manifested with severe pulmonary haemorrhagic syndrome successfully treated with venovenous extracorporeal membrane oxygenation. BMJ Case Rep. 2020;13(1):e230075.

14. Cantwell T, Ferre A, Van Sint JN, Blamey R, Dreyse J, Baeza C, et al. Leptospirosis-associated catastrophic respiratory failure supported by extracorporeal membrane oxygenation. J Artif Organs. 2017;20(4):371-6.

15. Kutlesa M, Gjurasin B. Leptospirosis-associated hemorrhagic pneumonitis successfully treated by venovenous extracorporeal membrane oxygenation: a case report. Croatian Journal of Infection. 2017;37(2):57-9.

16. Ludwig B, Zotzmann V, Bode C, Staudacher DL, Zschiedrich S. Lethal pulmonary hemorrhage syndrome due to Leptospira infection transmitted by pet rat. ID Cases. 2017;8:84-86 Available from: doi: 10.1016/j.idcr.2017.04. 016.

17. Pardinas M, Mendirichaga R, Budhrani G, Garg R, Rosario L, Rico R, et al. Use of Aminocaproic Acid in Combination with Extracorporeal Membrane Oxygenation in a Case of Leptospirosis Pulmonary Hemorrhage Syndrome. Clin Med Insights Circ Resp Pulm Med. 2017;11: 1179548416686068. Available from. https://doi.org/10.1177/1179548416686068.

18. Umei N, Ichiba S. A case of leptospirosis-associated severe pulmonary hemorrhagic syndrome successfully treated with venovenous extracorporeal membrane oxygenation. Case Rep Crit Care. 2017:5369267. Available from. https://doi.org/10.1155/2017/5369267.

19. Héry G, Letheulle J, Flécher E, Quentin C, Piau C, Le Tulzo Y, et al. Massive intra-alveolar hemorrhage caused by Leptospira serovar Djasiman in a traveler returning from Laos. Journal of Travel Medicine. 2015;22(3):212-4.

20. Liao CY, Ben RJ, Wu HM, Chang SK, Liu MY, Chin HK, et al. Acute respiratory distress syndrome manifested by leptospirosis successfully treated by extracorporeal membrane oxygenation (ECMO). Intern Med. 2015;54(22): 2943-6.

21. Kahn JM, Müller HM, Kulier A, Keusch-Preininger A, Tscheliessnigg KH. Venoarterial extracorporeal membrane oxygenation in acute respiratory distress syndrome caused by leptospire sepsis. Anesth Analg. 2006;102(5):1597-8.

22. Arokianathan D, Trower K, Pooboni S, Sosnowski A, Moss P, Thaker H. Leptospirosis: a case report of a patient with pulmonary haemorrhage successfully managed with extra corporeal membrane oxygenation. J Infect. 2005;50(2):158-62.

23. Bartakke AA, Muench C. A case of pulmonary haemorrhage and acute kidney injury. JICS. 2014;15(1):74-6.

24. Perez Rodriguez NM, Galloway R, Blau DM, Traxler R, Bhatnagar J, Zaki SR et al. Case report: case series of fatal Leptospira spp./dengue virus coinfections-Puerto Rico, 2010-2012. Am. J. Trop. Med. Hyg., 91 (4), 2014, pp. 760-765.

25. Rodrigo C. Lakshitha de Silva N, Goonaratne R, Samarasekara K, Wijesinghe I, Parththipan B, et al. High dose corticosteroids in severe leptospirosis: a systematic review. Trans R Soc Trop Med Hyg. 2014;108(12):743-50. 
26. Shenoy W, Nagar VS, Chowdhury AA, Bhalgat PS, Juvale NI. Pulmonary leptospirosis: an excellent response to bolus methylprednisolone. Postgrad Med J. 2006;82(971):602-6.

27. Kularatne SA, Budagoda BD, de Alwis VK, Wickramasinghe WM, Bandara JM, Pathirage LP, et al. High efficacy of bolus methylprednisolone in severe leptospirosis: a descriptive study in Sri Lanka. Postgrad Med J. 2011;87(1023): $13-7$

28. Ittyachen AM, Lakshmanakumar VK, Eapen CK, Joseph MR.

Methylprednisolone as adjuvant in treatment of acute respiratory distress syndrome owing to leptospirosis - a pilot study. Indian J Crit Care Med. 2005:9(3):133-6.

29. Niwattayakul K, Kaewtasi S, Chueasuwanchai S, Hoontrakul S, Chareonwat S, Suttinont $\mathrm{C}$, et al. An open randomized controlled trial of desmopressin and pulse dexamethasone as adjunct therapy in patients with pulmonary involvement associated with severe leptospirosis. Clin Microbiol Infect. 2010; 16(8):1207-12

\section{Publisher's Note}

Springer Nature remains neutral with regard to jurisdictional claims in published maps and institutional affiliations.

Ready to submit your research? Choose BMC and benefit from:

- fast, convenient online submission

- thorough peer review by experienced researchers in your field

- rapid publication on acceptance

- support for research data, including large and complex data types

- gold Open Access which fosters wider collaboration and increased citations

- maximum visibility for your research: over $100 \mathrm{M}$ website views per year

At BMC, research is always in progress.

Learn more biomedcentral.com/submissions 